\title{
The role of NF-KB and estrogen receptor on prostate cancer progression to bone metastasis
}

\section{Review}

Prostate cancer is the sixth highest cause of mortality in men world-wide. ${ }^{1}$ Some patients die suddenly, while others experience a rapid development to a life threatening disease. ${ }^{1}$ The year 2015 recorded 27, 540 prostate cancer (PCa) deaths, ${ }^{2}$ possibly as result of bone metastasis. The skeleton is known for metastatic activities and bone break down is the primary cause of cancer death. The occurrence of bone metastases makes the initial cancer incurable. ${ }^{3}$

Inflammation in general and NF- $\mathrm{KB}$ specifically have a multiple action in cancer. NF- $\kappa \mathrm{B}$ activities attack and eliminate neoplasia cells. Complete activation of NF- $\mathrm{BB}$ is followed by a high reaction of immune cells fighting against transformed cells. ${ }^{4} \mathrm{NF}-\mathrm{\kappa B}$ cross talk controls numerous life supporting mechanisms, such as cell proliferation $^{5}$ and apoptosis. ${ }^{5}$

$\mathrm{NF}-\mathrm{kB}$ was first known as a transcription factor in 1986. It was described as a nuclear factor attached to the DNA of the immunoglobulin kappa light-chain of activated B cells. ${ }^{6}$ Consequently, proteins which possess this special DNA binding activity are functional in most cell types and control many related genes with numerous functions. ${ }^{7}$

Numerically, five divisions of transcription factor family have been classified. These are tagged as p65 (RelA), RelB, c-Rel, NF$\kappa B 1$ and NF- $\kappa B 2$. In dissimilarity to the other family divisions, NF$\kappa \mathrm{B} 1$ and NF- $\kappa \mathrm{B} 2$ are produced in inactive forms (p105 and p100) and are enzymatically broken down to the active forms (p50 and p52), respectively. ${ }^{8}$ All the five divisions of this protein family tree form homo- or heterodimers and have similar structural features. They have Rel homology domain (RHD). RHD is important for combination, as well as linking to associate DNA elements. ${ }^{9}$ NF- $\kappa B$ sub units consist of regions for phosphorylations and other after-translational alterations. These regions are necessary for activation and signal transduction link with other signaling pathways. ${ }^{10}$ Attachment of NF$\kappa \mathrm{B}$ dimers to I $\mathrm{B}$ molecules hinder binding to DNA, and shift the balance-state localization of the complex to the cytoplasm. In spite of that, movement between cytoplasm and nucleus takes place. ${ }^{11}$

Numerous activation processes ensure that various stress circumstances can initiate the enzymatic activities of IKKs. These cause the bio-availability of the general stress response factor NF$\kappa \mathrm{B}$. Furthermore, they provide a basis for complex signal transduction with other signaling pathways. It is likely that many of the feedback inhibitors are de-ubiquitinases (DUB's) such as A20 ${ }^{7}$ or CYLD. ${ }^{12}$

Bone metastasis occurs often in the fourth stage of prostate cancer. This leads to serious diseases including pain, disease causing broken bone, spinal cord deformity, and disability. Systemic androgen deprivation is effective in controlling metastasis. However, the metastatic mass eventually become resistant to hormonal or chemotherapeutic treatment and continue to multiply. ${ }^{13}$

Bone metastases may lead to osteolytic, osteosclerotic, or mixed lesions. Osteolytic metastases occur as a result of increased action of bone-breaking cells, the osteoclasts (OCs). OCs damages the bone. ${ }^{14}$ About $65-75 \%$ of prostate cancer patients experience bone metastases during the development of cancer. ${ }^{15}$
Volume 5 Issue I - 2016

Toluleke Oloruntobi Famuyiwa

Department of Biological Sciences, Florida Atlantic University, USA

Correspondence: Toluleke Oloruntobi Famuyiwa, Department of Biological Sciences, Florida Atlantic University,3200 College Avenue, Davie, USA, Tel I (954) 5I2- 3875, Email tfamuyiwa2014@fau.edu

Received: April 07, 2016| Published: May 17, 2016

The NF- $\kappa$ B pathway is also a key mediator of genes responsible for cellular proliferation and apoptosis. ${ }^{16}$ The inhibition of NF- $\mathrm{kB}$ trans activation may be part of a negative feedback loop that contributes to resolution of inflammation and cancer. ${ }^{16}$

Osteoprotegerin (OPG) is a decoy receptor for Receptor Activator of Nuclear Factor Kappa-B ligand (RANKL). OPG binds to RANKL, this leads to reduced production of osteoclasts by inhibiting the maturation of osteoclast precursors. Bone resorption/remodeling are a complex process regulated by a large variety of molecules. ${ }^{17}$ The RANKL to OPG magnitude is the key regulatory determinant of bone resorption. Bone resorption is favored by high RANKL to OPG ratio. ${ }^{17}$ Genistein $(10 \mathrm{mg} / \mathrm{kg}$, in subcutaneous administration) significantly increased serum OPG level as well as decreased serum RANKL level and the RANKL/OPG ratio in ovariectomized rats. ${ }^{18}$ Therefore, impacting apoptosis induction through NF-KB inhibition.

The effect of vitamin $\mathrm{C}$ on NF- $\mathrm{KB}$ in vitro suggests concentration dependent; one study indicated that $0.2 \mathrm{mM}$ ascorbate enhanced NF$\kappa \mathrm{B}$ activation in Jurkat T-cells, ${ }^{19}$ while two other studies using higher ascorbate concentrations showed inhibition of NF- $\mathrm{KB}$ in endothelial cell $\mathrm{s}^{20}$ and other human cell types. Combination treatment of genistein and vitamin $\mathrm{C}$ permits more $\mathrm{LNCaP}$ prostate cancer cells to live than the single treatment of genistein in vitro, although there was more apoptosis in the combination treatment of genistein and vitamin C. ${ }^{21}$ Future studies should evaluate a possible synergy between the combination treatment (genistein and vitamin $\mathrm{C}$ treatment) and NFKB pathway inhibition.

Studies have characterized the constituent of exosomes liberated by the metastatic prostate cancer cell line PC-3 at the polypeptide, ${ }^{21}$ $\operatorname{lipid}^{23}$ and micro RNA step. ${ }^{24}$ It has been suggested that inhibition of V-ATPase impacts prostate cancer invasion and PSA level..$^{25,26}$ In the same vein, down-regulation of LASS2/TMSG1 (which decreases V-ATPase activity through V0c-attachment) led to greater metastasis and prostate cancer growth. ${ }^{27}$ Exosomes are one of the tumor derived factors inducing vascular leakiness, inflammation and bone marrow progenitor cell recruitment during pre-metastatic niche formation and metastasis. $^{28}$ 
Surprisingly, bone-tropic exosomes expressed a limited integrin store, but were capable of inducing vascular leakiness in the lung. Although, induction of vascular leakiness may be the first exosomemediated step during the metastatic cascade, it is insufficient to promote bonemetastasis. Integrin-dependent mechanisms may not mediate vascular leakiness and exosome activity in bone metastasis. ${ }^{29}$

In $\mathrm{kB}$ site-dependent reporter gene assays, ER-alpha has been shown to down regulate NF-kB activity in an estrogen-dependent mechanism at Nano molar concentrations of estrogen. This occurs in many cell lines, such as U2-OS, ${ }^{30} \mathrm{~F} 9,{ }^{31} \mathrm{HeLa},{ }^{32,33} 293,{ }^{34} \mathrm{U} 937,{ }^{35}$ HepG $2^{36}$ and MCF- $7^{37}$ cells. Many groups have also shown that ER-b has an inhibitory effect on NF-kB activity. ${ }^{32-39}$

The cross-talk between these transcription factors suggests relevance to bone physiology, inflammation, cancer and autoimmune diseases. However, the process of down-regulation of NF-kB by ER is manifold and may be specific to cell type and context. Many essential technical questions remain unanswered about the signal transduction between the ER and NF-kB. What is the extent of the inhibition of NF-kB target genes by ER-alpha? What percentage of NF-kB target genes is inhibited by ER-alpha? Studies have shown that ER-alpha can selectively inhibit NF-kB target genes; ER-alpha inhibits NF-kB-mediated transcriptional induction of the IL-6 gene in almost all cancer types, but not that of the TRAF1 (Tumor necrosis factor receptor-associated factor 1) gene in the MDA-MB-231 breast cancer cell line. ${ }^{40}$ Are there particular SERMs (Selective Estrogen Receptor Modulators) that enhance the ability of the ER to repress NF-kB activity? And can these SERMs be used to counter NF-kB activity in some diseases? Does the ER exert its anti- or pro-apoptotic effects through modulation of NF-kB? Finding the solutions to these questions will supply a beneficial need for further research.

\section{Conclusion}

In summary, NF-kB induced expression of the gene encoding IL6. This contributes to breaking down of bone tissue. ${ }^{41}$ Members of the NF-kB family function to promote bone resorption through the regulation of cytokines such as interleukein-6 (IL-6) ${ }^{41}$ and estrogen acts to inhibit this process. ${ }^{42}$ Furthermore, the anti-inflammatory roles of the ER in many animal models of disease and human disorders ${ }^{42-44}$ might be explained by inhibition of the pro-inflammatory activities of NF-kB..$^{45}$

RANKL is an important factor for osteoclastogenesis because it stimulates maturation of myeloid precursor cells into osteoclasts by binding to its signaling receptor. ${ }^{46}$ RANKL expression was shown to be induced by IL-6/ sIL-6R but not IL-6 alone via the JAK/STAT signaling pathway. ${ }^{46}$ Appropriately, neutralizing anti-IL-6mAbs inhibited osteoclast production. IL-6 levels and some IL-6 gene polymorphisms have been associated with bone mineral density alterations in inflammatory disease. ${ }^{47}$ IL-6 plays an important role in the regulation of bone metastasis, presumably via IL- 6 trans-signaling.

The NF-kB group of transcription factors direct numerous aspects of the immune and skeletal systems' inflammatory responses. Chronic NF-kB activity has been implicated in various diseases including arthritis, diabetes, atherosclerosis, Alzheimer's disease and several cancers. ${ }^{48,49}$ Future studies should evaluate a possible synergy between the combination treatment (genistein and vitamin $C$ treatment) and NF-KB pathway inhibition. Concerted research effort should be on studying integrin-independent mechanisms mediating vascular leakiness and exosome involvement in bone metastasis.

\section{Acknowledgments}

None.

\section{Conflicts of interest}

The author declares that there is no conflict of interest.

\section{Funding}

None.

\section{References}

1. Mitchell RE, Chang SS. Current controversies in the treatment of highrisk prostate cancer. Curr Opin Urol. 2008;18(3): 263-268.

2. NCI. SEER Cancer statistics factsheets: Prostate Cancer. National Cancer Institute. Bethesda, USA;2016.

3. Coleman RE. Clinical features of metastatic bone disease and risk of skeletal morbidity. Clin Cancer Res. 2006;12(20 pt 2): 6243s-6249s.

4. Guttridge DC, Albanese C, Reuther JY, Pestell RG, Baldwin AS. NFkappaB controls cell growth and differentiation through transcriptional regulation of cyclin D1. Mol Cell Biol. 1999;19(8): 5785-5799.

5. Perkins ND. Achieving transcriptional specificity with NF-kappa B. Int J Biochem Cell Biol. 1997;29: 1433-1448.

6. Sen R, Baltimore D. Multiple nuclear factors interact with the immunoglobulin enhancer sequences. Cell. 1986;46(5): 705-716.

7. May MJ, Ghosh S. Signal transduction through NF-kappa B. Immunol Today. 1998;19(2): 80-88.

8. Caamaño J, Hunter CA. NF-kappaB family of transcription factors: central regulators of innate and adaptive immune functions. ClinMicrobiol Rev. 2002;15(3): 414-429.

9. May MJ, Ghosh S. Rel/NF-kappa B and I kappa B proteins: an overview. Semin Cancer Biol. 1997;8(2): 63-73.

10. Oeckinghaus A, Ghosh S. The NF- B family of transcription factors and its regulation. Cold Spring Harb Perspect Biol. 2009;1(4): a000034.

11. Birbach A, Gold P, Binder BR, et al. Signaling molecules of the NF-kappa B pathway shuttle constitutively between cytoplasm and nucleus. J Biol Chem. 2002;277(13):10842-10851.

12. Wertz IE, O'Rourke KM, Zhou H, et al. De-ubiquitination and ubiquitin ligase domains of A20 downregulate NF-kappaBsignalling. Nature. 2004;430(7000):694-699.

13. Li Y, Che M, Bhagat S, et al. Regulation of Gene Expression and Inhibition of Experimental Prostate Cancer Bone Metastasis by Dietary Genistein. Neoplasia. 2004;6(4):354-363.

14. Coleman RE. Bisphosphonates:clinical experience. Oncologist. 2004;9(4):14-27.

15. JE Compston. Bone marrow and bone:a functional unit. $J$ Endocrinol. 2002;173(3):387-394

16. Barkett M, Gilmore TD. Control of apoptosis by Rel/NFkappaB transcription factors. Oncogene. 1999;18(49):6910-6924.

17. Sliwiński L, Folwarczna J, Nowińska B, et al. A comparative study of the effects of genistein, estradiol and raloxifene on the murine skeletal system. ActaBiochim Pol. 2009;56(2):261-270.

18. Bitto A, Burnett BP, Polito F, et al. Effects of genisteinaglycone in osteoporotic, ovariectomized rats:a comparison with alendronate, raloxifene and oestradiol. Br J Pharmacol. 2008;155(6):896-905. 
19. Munoz E, Blazquez MV, Ortiz C, et al. Role of ascorbate in the activation of NF-kappa B by tumor necrosis factor-a in T-cells. Biochem $\mathrm{J}$. 1997;325(pt 1):23-28.

20. Bowie AG, O’Neill LAJ. Vitamin C inhibits NF-kappa B activation by TNF via the activation of p38 mitogen-activated protein kinase $1 . J$ Immunol. 2000;165(12):7180-7188.

21. Toluleke OF, Andrew B, James KD, et al. Enhancement of GenisteinInduced Apoptosis in LNCaP Prostate Cancer cells. J Cancer Prev Curr Res. 2016;4(2):1-11.

22. Sandvig K, Llorente A. Proteomic analysis of microvesicles released by the human prostate cancer cell line PC-3. Mol Cell Proteomics. 2012;11(7):M111.

23. Llorente A, Skotland T, Sylvanne T, et al. Molecular lipidomics of exosomes released by $\mathrm{PC}-3$ prostate cancer cells. Biochim Biophys Acta. 2012;1831(7):1302-1309.

24. Hessvik NP, Phuyal S, Brech A, et al. Profiling of microRNAs in exosomes released from PC-3 prostate cancer cells. Biochim Biophys Acta. 2012;1819(11-12):1154-1163.

25. Michel V, Licon MY, Trujillo K, et al. Inhibitors of vacuolar ATPase proton pumps inhibit human prostate cancer cell invasion and prostatespecific antigen expression and secretion. Int J Cancer. 2013;132(2):110 .

26. Sennoune SR, Bermudez LE, Lees JC, et al. Vacuolar H+-ATPase is downregulated by the angiogenesis-inhibitory pigment epitheliumderived factor in metastatic prostate cancer cells. Cell Mol Biol. 2014;60(1):45-52.

27. Xu X, Liu B, Zou P, et al. Silencing of LASS2/TMSG1 enhances invasion and metastasis capacity of prostate cancer cell. J Cell Biochem. 2014;115(4):731-743.

28. Peinado H, Alečković M, Lavotshkin S, et al. Melanoma exosomes educate bone marrow progenitor cells toward a pro-metastatic phenotype through MET. Nat Med. 2012;18(6):883-891.

29. Hoshino A, Costa Silva B, Shen TL, et al. Tumor exosome integrins determine organotropic metastasis. Nature. 2015;527(7578):329-335.

30. Stein B, Yang MX. Repression of the interleukin-6 promoter by estrogen receptor is mediated by $\mathrm{NF}-\mathrm{kB}$ and $\mathrm{C} / \mathrm{EBPb}$. Mol Cell Biol. 1995;15(9):4971-4979.

31. Ray A, Prefontaine KE, Ray P. Down-modulation of interleukin-6 gene expression by $17 \mathrm{~b}$-estradiol in the absence of high affinity DNA binding by the estrogen receptor. J Biol Chem. 1994;269(17):12940-12946.

32. Cerillo G, Rees A, Manchanda N, et al. The oestrogen receptor regulates NFkB and AP-1 activity in a cell specific manner. $J$ Steroid Biochem Mol Biol. 1998;67(2):79-88.

33. Valentine JE, Kalkhoven E, White R, et al. Mutations in the estrogen receptor ligand binding domain discriminate between hormonedependent transactivation and transrepression. $J$ Biol Chem. 2000;275(33):25322-25329.
34. Kalaitzidis D, Ok J, Sulak L, et al. Characterization of a human RELestrogen receptor fusion protein with a reverse conditional transforming activity in chicken spleen cells. Oncogene. 2004;23(45):7580-7587.

35. Tzagarakis FC, Geleziunas R, Lomri A, et al. Estradiol represses human T-cell leukemia virus type 1 Tax activation of tumor necrosis factor-a gene transcription. J Biol Chem. 2002;277(47):44772-44777 .

36. Harnish DC, Scicchitano MS, Adelman SJ, et al. The role of CBP in estrogen receptor cross-talk with nuclear factor-kB in HepG2 cells. Endocrinology. 2000;141(19):3403-3411.

37. Hsu SM, Chen YC, Jiang MC. 17b-Estradiol inhibits tumor necrosis factor-ainduced nuclear factor- $\mathrm{kB}$ activation by increasing nuclear factor-kB p105 level in MCF-7 breast cancer cells. Biochem Biophys Res Commun. 2000;279(1):47-52.

38. Speir E, Yu ZX, Takeda K, et al. Antioxidant effect of estrogen on cytomegalovirus-induced gene expression in coronary artery smooth muscle cells. Circulation. 2000;102(24):2990-2996.

39. Chu S, Nishi Y, Yanase T, et al. Transrepression of ERb signaling by NFkB in ovarian granulose cells. Mol Endocrinol. 2004;18(8):1919-1928.

40. Bhat NP, Campbell RA, Patel NM, et al. Tumour necrosis factor and PI3kinase control oestrogen receptor a protein level and its transrepression function. Br J Cancer. 2004;90(4):853-859.

41. Boyce BF, Xing L, Franzoso G, et al. Required and nonessential functions of nuclear factor-kB in bone cells. Bone. 1999;25(1):137-139.

42. Pfeilschifter J, Köditz R, Pfohl M, et al. Changes in proinflammatory cytokine activity after menopause. Endocr Rev. 2002;23(1):90-119.

43. Vegeto E, Belcredito S, Etteri S, et al. Estrogen receptor-a mediates the brain anti-inflammatory activity of estradiol. Proc Natl Acad Sci USA. 2003;100(16):9614-9619.

44. Shim GJ, Kis LL, Warner M, et al. Autoimmune glomerulonephritis with spontaneous formation of splenic germinal centers in mice lacking the estrogen receptor a gene. Proc Natl Acad Sci USA. 2004;101(6):17201724.

45. Andreakos E. The role of NF-kB in inflammatory diseases. Nuclear Factor kB:Regulation and Role in Disease. In:Beyaert R, editors. Kluwer Academic Publishers, Germany. 2003. p. 295-323.

46. Hashizume M, Hayakawa N, Mihara M. IL-6 trans-signaling directly induces RANKL on fibroblast-like synovial cells and is involved in RANKL induction by TNF-alpha and IL-17. Rheumatology. 2008;47(11):1635-1640.

47. Tilg H, Moschen AR, kaser A, et al. Gut, inflammation and osteoporosis:basic and clinical concepts. Gut. 2008;57(5):684-694.

48. Kumar A, Takada Y, Boriek AM, et al. Nuclear factor-kB:its role in health and disease. J Mol Med. 2004;82(7):434- 448.

49. Hayden MS, Ghosh S. Signaling to NF-kB. Genes Dev. 2004;18(18):2195-2224. 